\title{
Substituent Effects of Halogen Atoms on Regioselective Tritiation of Benzanilides
}

\author{
Kunio OoHashi, Norihisa Kitayama and Yoshiharu SHINOda \\ Department of Chemistry, College of Arts and Sciences, \\ Chiba University \\ Yayoi, Inage-ku, Chiba-shi 263, Japan
}

Received July 20, 1992

\begin{abstract}
$\mathrm{RhCl}_{3}$ catalyzed regioselective tritiation of benzanilide and para-halobenzanilides with HTO was studied to examine the substituent effects of halogen atoms on the tritium incorporation to the anilino benzene ring. It was established by chemical degradation that the tritiation occurred with virtually $100 \%$ regioselectivity at the o-positions of both the benzene rings in the benzanilides. The p-substituted halogen atoms increased the tritium incorporation ratios of the anilino benzene ring to the benzoyl benzene ring, which in the present hydrogen isotope exchange was considered as an intramolecular reference standard for the tritium incorporation. The average ratios obtained from the respective duplicates were $0.386,1.20,1.61$ and 1.74 in the order of benzanilide, $p-\mathrm{F}-, p-\mathrm{Cl}$ - and $p-\mathrm{Br}$-benzanilides. On the basis of the results, the reaction mechanism is briefly discussed.
\end{abstract}

Key Words : substituent effect, halogen, regioselectivity, tritiation, tritiated water, benzanilide, rhodium(II) chloride

\section{Introduction}

Tritiated water or deuterium oxide labels the $o$-positions of various aromatic acids, anilides, amides, and amines with high regioselectivity in the presence of $\mathrm{RhCl}_{3} \cdot 3 \mathrm{H}_{2} \mathrm{O}$ through the hydrogen isotope exchange reac$\operatorname{tion}^{1-7)}$. At early stage of the study, the regioselectivity was noted from the synthetic viewpoint $^{1-4)}$. When the hydrogen isotope exchange with $\mathrm{D}_{2} \mathrm{O}$ or HTO is catalyzed by acids, metals, or even by metal complexes, generally low regioselectivity is exhibited. This is because the exchange reactions are initiated via the interaction of $\pi$-electrons of the aromatic ring with the catalyst ${ }^{8)}$. Recently some studies with HTO were devoted to shed light on the mechanism of the present hydrogen isotope exchange reaction ${ }^{5), 6)}$. The regioselectivity was established for acetanilide and benzoic acid etc. by chemical degrada- tion. It has been suggested on the basis of the experimental results that the observed regioselectivity arises via an initial coordination of the nitrogen atom of the acetamide group or of the negatively charged oxygen atom in benzoate ion to the rhodium(III) chloride catalyst. Complexes of rhodium with pyridine or some carboxylates have been reported $^{9), 10)}$. Quite recently a contribution of the electronic and steric effects was reported on the regioselective tritiation of anilides ${ }^{7}$. The results give support to the above reaction processes.

A previous study on acetanilide disclosed the effects of $p$-substituted halogen atoms on the extent of tritium incorporation, but it was unsuccessful in revealing a difference in the substituent effect between them ${ }^{5}$. The present experiments were performed to examine the substituent effects of halogen atoms in detail with benzanilide and $p$-halobenzani- 
lides having the benzoyl benzene ring regarded as an intramolecular reference standard for the tritium incorporation. The experimental results indicated clearly a difference in the substituent effect among the three halogen atoms. Information on regioselectivity was obtained by chemical degradation.

\section{Experimental}

Reagent grade benzanilide was obtained from Tokyo Kasei Kogyo Co. Ltd. $p$-Halobenzanilides were prepared by reactions between benzoyl chloride and the corresponding anilines of reagent grade, which were obtained from Wako Pure Chemical Industries, Ltd. or Tokyo Kasei Kogyo Co. Ltd. The benzanilides were purified by repeated crystallization. Calcd for benzanilide: C: 79.17; H: 5.62; $\mathrm{N}: 7.10$. Found: $\mathrm{C}: 79.14 ; \mathrm{H}: 5.69 ; \mathrm{N}: 7.11$. Calcd for $p$-fluorobenzanilide: $\mathrm{C}: 72.55 ; \mathrm{H}$ : $4.68 ; \mathrm{N}: 6.51$. Found: $\mathrm{C}: 72.54 ; \mathrm{H}: 4.85 ; \mathrm{N}$ : 6.74. Calcd for $p$-chlorobenzanilide: C: 67.40 ; $\mathrm{H}: 4.35 ; \mathrm{N}: 6.05$. Found: C: $67.23 ; \mathrm{H}: 4.38$; $\mathrm{N}:$ 5.98. Calcd for $p$-bromobenzanilide: $\mathrm{C}$ : $56.55 ; \mathrm{H}: 3.65 ; \mathrm{N}: 5.07$. Foud: C: $56.51 ; \mathrm{H}$ : 3.68; N: 5.01. Rhodium(III) chloride trihydrate, $N, N$-dimethylformamide (DMF), and tritiated water were described elsewhere ${ }^{5}$. The specific activity was determined by using $\left[{ }^{3} \mathrm{H}\right]$ hexadecane obtained from Amersham International Public Limited Company (hereafter abbreviated as Amersham) as a radioactivity standard.

The substrate benzanilide $(1.2 \mathrm{mmol})$, rhodium(III) chloride trihydrate $(158 \mathrm{mg})$, and tritiated water $(0.6 \mathrm{ml})$ were dissolved in $6 \mathrm{ml}$ of DMF. Then $1.2 \mathrm{ml}$ portions of the mixture were heated in five $\mathrm{V}$-vials at $105-107 \mathrm{C}$ for $11 \mathrm{~h}$, which was a long time enough for the tritium incorporation to level off. After cooling, isolation and purification of the substrate compounds were carried out in similar procedures to those described elsewhere ${ }^{5)}$. To examine the intramolecular tritium distribution and the extent of tritium incorporation to both the benzene rings, the parent benzanilides were hydrolyzed to obtain benzoic acid and the respective anilines, followed by syntheses of their derivatives. The benzanilides and their derivatives were purified by repeated crystallization to be a constant count. Radioactivity of tritium was measured in a toluene-based scintillator (PPO: $4 \mathrm{~g}$ and DMPOPOP: $0.2 \mathrm{~g} \mathrm{dm}^{-3}$ ) or in ACS II scintillator from Amersham by an Aloka liquid scintillation system model 3050. Each sample was counted for a period sufficient to reduce the standard deviation to $0.5 \%$ or less at 2 sigma

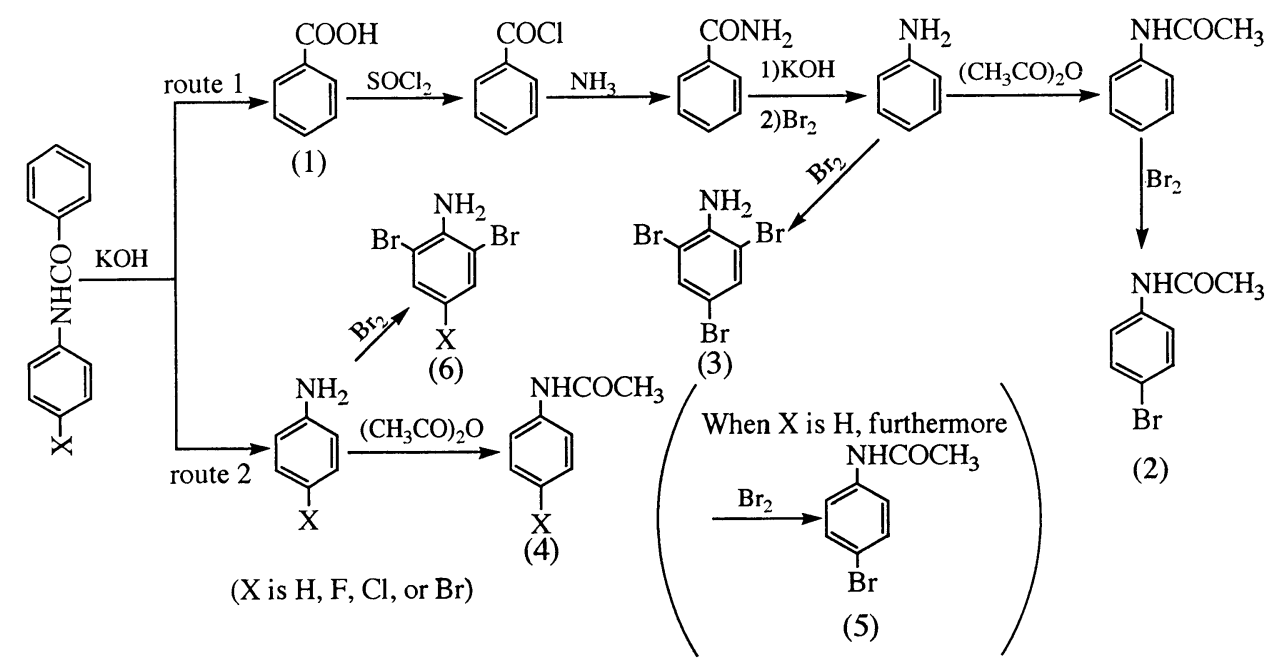

Fig. 1 Synthetic scheme of derivatives. 
confidence level. The specific activity of tritium labeled compounds was determined from the count rate as described elsewhere ${ }^{11}$.

\section{Results and Discussion}

Figure 1 shows schematically the synthetic sequence of the derivatives from the parent benzanilides. Their specific activities ( $\mathrm{MBq}$ $\mathrm{mol}^{-1}$ ) are summarized in Table 1 . The specific activities of tritiated water used are 31.8 $\mathrm{MBq} \mathrm{g}^{-1}$ in Run 1 for benzanilide and 92.5 $\mathrm{MBq} \mathrm{g}^{-1}$ for all the other runs. Taking into account the situation, the extent of tritium incorporation to the parent benzanilides was reproduced within the experimental error in all the duplicates. In addition, in every run the combined specific activity of benzoic acid and aniline (or $p$-haloaniline) obtained by hydrolysis was in accord with the specific activity of the parent benzanilide within $1 \%$ relative to each other. Aniline and $p$-haloanilines were purified as the acetyl compounds to determine the specific activities. The location of tritium in both the benzene rings of the benzanilides can be determined using the specific activities of the derivatives shown in Table 1 in a similar manner as described elsewhere in detai15),6). Consequently it is indicated that the present hydrogen isotope exchange occurred at the $o$-positions of both the benzene rings with virtually $100 \%$ regioselectivity.

It has been suggested that the $\mathrm{RhCl}_{3}$ catalyzed tritiation with HTO is initiated in acetanilide via the coordination of the nitrogen lone pair of electrons to the catalyst and in benzoic acid via the coordination of the carboxylate ion to the catalyst ${ }^{5), 6)}$. Methyl benzoate was inactive for the present tritiation ${ }^{6}$. $p$-Methoxybenzaldehyde did not show substantial catalytic labeling with $\mathrm{D}_{2} \mathrm{O}$, whilst p-methoxybenzamide did a high percentage exchange with $\mathrm{D}_{2} \mathrm{O}^{2}$. These findings indicate that the carbonyl group itself does not contribute to promoting the present exchange and
Table 1 Specific activities of parent anilides and their derivatives

\begin{tabular}{lcccc}
\hline $\begin{array}{l}\text { Parent } \\
\text { compound }\end{array}$ & Route & Derivative & \multicolumn{2}{c}{$\begin{array}{c}\text { Specific activity } \\
\left(\mathrm{MBq} \mathrm{mol}^{-1}\right) \\
\text { Run 2 }\end{array}$} \\
\hline Benzanilide & & & 23.7 & 68.7 \\
\hdashline & & $(1)$ & 17.0 & 50.0 \\
& & $(2)$ & 17.0 & 50.2 \\
& & $(3)$ & $*$ & $*$ \\
& & $(4)$ & 6.57 & 19.3 \\
& & $(5)$ & 6.61 & 19.2 \\
& & $(6)$ & $*$ & $*$ \\
\hline
\end{tabular}

\begin{tabular}{|c|c|c|c|c|}
\hline $\begin{array}{l}p \text {-Fluorobenz- } \\
\text { anilide }\end{array}$ & & & 102 & 102 \\
\hline & & (1) & 46.6 & 46.8 \\
\hline & 1 & (2) & 46.8 & 47.0 \\
\hline & & (3) & $*$ & $*$ \\
\hline & 2 & (4) & 55.8 & 55.8 \\
\hline & & (6) & $*$ & $*$ \\
\hline \multirow[t]{6}{*}{$\begin{array}{l}p \text {-Chlorobenz- } \\
\text { anilide }\end{array}$} & & & 105 & 106 \\
\hline & & (1) & 39.7 & 40.7 \\
\hline & 1 & (2) & 39.9 & 40.6 \\
\hline & & (3) & $*$ & $*$ \\
\hline & 2 & (4) & 64.0 & 65.6 \\
\hline & & (6) & $*$ & $*$ \\
\hline \multirow[t]{6}{*}{$\begin{array}{l}p \text {-Bromobenz- } \\
\text { anilide }\end{array}$} & & & 108 & 107 \\
\hline & & (1) & 39.7 & 39.6 \\
\hline & 1 & (2) & 39.7 & 39.9 \\
\hline & & (3) & $*$ & $*$ \\
\hline & 2 & (4) & 69.3 & 67.9 \\
\hline & & (6) & $*$ & $*$ \\
\hline
\end{tabular}

1) Specific activity of tritiated water: $31.8 \mathrm{MBq}$ $\mathrm{g}^{-1}$ for Run 1 of benzanilide and $92.5 \mathrm{MBq} \mathrm{g}^{-1}$ for the other runs.

2) The numbers in parentheses stand for the derivatives of the same numbers in Fig. 1, respectively.

3) The specific activities of the parent benzanilides were normalized to that of $\left[{ }^{3} \mathrm{H}\right]$ hexadecane from Amersham stated above. The accuracy of specific activities of the derivatives from benzoic acid and aniline is estimated to be $1 \%$ relative to the specific activities of the respective parent compounds.

${ }^{*}$ The measured tritium activity of the corresponding counting sample was of a background level. 
suggest an action of the nitrogen atom as the ligand, though the possibility of an additional contribution from the carbonyl group conjugated with the nitrogen atom may be present. The situation should be also the case for the tritiation of benzanilide. That is to say, the $o$-positions of both the benzene rings in a benzanilide molecule are presumed to be tritiated via the identical interaction of the nitrogen atom (or the $-\ddot{\mathrm{NH}}-\mathrm{C}=\mathrm{O}$ conjugated system) with the catalyst.

Previously it was reported in the present regioselective $\mathrm{T}$-for- $\mathrm{H}$ exchange reaction for acetanilide that the chloro- or bromo-substituent at the $p$-position enhanced the extent of tritium incorporation to the o-positions ${ }^{5)}$. A clear difference in the substituent effect, however, could not be observed between two of them. In the present tritiation of benzanilides, a similar tendency is also seen in Table 1 for the extent of tritium incorporation. All the three halogen atoms promote the exchange, but only small differences in the specific activities were observed among the three $p$ halobenzanilides.

As an attempt to examine the substituent effect of halogen atoms in further detail, were calculated the tritium incorporation ratios of the anilino benzene ring to the benzoyl benzene ring regarded as an intramolecular reference standard and shown in Fig. 2. The calculation was performed using the specific activities of aniline (or $p$-haloaniline) and benzoic acid came from each parent benzanilide. Consequently, not only the effect of halogen atom-substitution was indicated clear$1 y$, but also differences in the effect were revealed among the three halogen atoms. The extent of tritium incorporation is influenced by variation in the nitrogen lone pair electron density ${ }^{7)}$. The ratio of tritium incorporation into both the benzene rings, however, should be independent of the change in the density, because in the present exchange reaction the $o$-positions in both the benzene rings of the

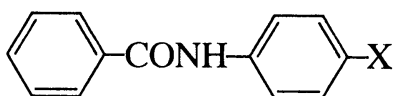

(A)

(B)

$\begin{array}{lllll}\mathrm{X}=\mathrm{H} & \text { run 1 } & 1 & \vdots & 0.387 \\ & \text { run 2 } & 1 & \vdots & 0.385 \\ \mathrm{X}=\mathrm{F} & \text { run 1 } & 1 & \vdots & 1.20 \\ & \text { run 2 } & 1 & \vdots & 1.19 \\ \mathrm{X}=\mathrm{Cl} & \text { run 1 } & 1 & \vdots & 1.61 \\ & \text { run 2 } & 1 & \vdots & 1.61 \\ \mathrm{X}=\mathrm{Br} & \text { run 1 } & 1 & \vdots & 1.75 \\ & \text { run 2 } & 1 & \vdots & 1.72\end{array}$

Fig. 2 Tritium incorporation ratios of (B) ring/(A) ring.

parent benzanilides are considered to be tritiated through the identical intramolecular process based on the interaction of the nitrogen atom and catalyst.

The tritium incorporation ratio was in creased by the substitution of halogen atom at the $p$-position of the anilino benzene ring and in addition, increased in the order of the substitution of $\mathrm{F}, \mathrm{Cl}$, and $\mathrm{Br}$. In the present exchange reaction the expected substitution effect is only the electronic effect and the steric effect is not included in it. The electronic effect is further separated into those on the two positions in the substrate molecule. One is that on the lone pair electron density of the nitrogen atom via the carbon position opposite to halogen atom and another is that on the $m$-positions of halogen atom as the substituent, i.e. on the positions at which the exchange occurs.

The $p$-substituted halogen atoms enhanced the extent of tritium incorporation to benzanilide. A major contributing factor to this will be the effect on the nitrogen lone pair electron density based on resonance propagating through the overlap of $p$ orbitals between halogen and carbon atoms. The resonance effect is not propagated to the adjacent benzoyl benzene ring, because in benzanilides the two benzene rings are not conjugated. Therefore, the benzoyl benzene ring, in the 
present tritiation, is accepted as a valid intramolecular reference standard substantially independent of the substituent effects of the halogen atoms on the tritium incorporation.

Another electronic effect is one on the positions at which the exchange occurs. These positions are the $m$-positions of the substituted halogen atom. An evident intermediate in the present reaction is not given so far. Information on the electronic effect, however, will be given at least qualitatively through the Hammett's substituent constant which indicates the relative electron-withdrawing or electron-releasing effect of a particular substituent. These values for the halogen atoms are all positive at the $m$-positions, which are referred to as the $\sigma$-positions in the benzanilide molecules, indicating that the halogen atoms act as the electron-withdrawing substituents on the positions. The largest tritium incorporation ratio was given by bromine atom having the largest $\sigma$-value $(0.391)$, followed by a decreasing order of chlorine (0.373), fluorine (0.337), and hydrogen (0.000) in benzanilide. The above relationship between the tritium incorporation ratio and the $\sigma$-value is not consistent with the mechanism of the electrophilic aromatic substitution. A recent study showed that electron-withdrawing substituents promoted the $\mathrm{T}$-for-H exchange between the proton-like carboxyl hydrogen of mono-substituted benzoic acids and gaseous $\mathrm{HTO}^{12)}$. Thus, at the present stage of know- ledge, a plausible mechanism is as follows; the present tritiation proceeds by the $\mathrm{T}$-for- $\mathrm{H}$ exchange between $\mathrm{C}-\mathrm{H}^{\delta+}$ at the $o$-positions and $\mathrm{O}-\mathrm{T}^{\delta+}$ of HTO as a ligand of rhodium (III) through some processes.

\section{References}

1) Lockley, W.J.S.: Tetrahedron Lett., 23, 3819-3822 (1982)

2) Lockley, W.J.S.: J. Label. Comp. Radiopharm., 21, 45-57 (1984)

3) Lockley, W.J.S.: ibid., 22, 623-630 (1985)

4) Lockley, W.J.S.: J. Chem. Res.(s), 178-179 (1985)

5) Oohashi, K., Nakamura, T. and Aoyama, Y.: J. Radioanal. Nucl. Chem. Lett., 145, 29-37 (1990)

6) Oohashi, K. and Soutome, Y.: ibid., 155, 65-73 (1991)

7) Oohashi, K. and Udo, M.: Radioisotopes, 41, 357-361 (1992)

8) Garnett, J.L.: Catalysis Rev., 5, 229-267 (1971)

9) Gillard, R.D. and Wilkinson, G.: $J$. Chem. Soc., 1224-1228 (1964)

10) Stephenson, T.A., Morehouse, S. M., Powell, A.R., Heffer, J.P. and Wilkinson, G. : ibid., 3632-3640 (1965)

11) Saito, T., Oohashi, K. and Morikawa, N.: Radioisotopes, 30, 596-598 (1981)

12) Okada, M., Imaizumi, H. and Hishiki, K.: ibid., 41, 241-246 (1992), in Japanese 
要旨

\section{ベンズアニリドの位置選択的トリチウム化に対する ハロゲン原子の置換基効果}

大橋國雄, 北山徳久, 篠田芳晴

千葉大学教養部化学教室

263 千葉市稲毛区弥生町 1-33

$\mathrm{RhCl}_{3} \cdot 3 \mathrm{H}_{2} \mathrm{O}$ の存在下に $\mathrm{HTO}$ を用いてベンズアニリドおよび $p$-ハロベンズアニリドをトリチ ウム化し，この水素同位体交換反応が二つのベンゼン環のオルト位で高度に位置選択的に起こるこ とを確認した。さらに，分子内ベンゾイル基のベンゼン環を基準として，三つのベンゼン環へのト リチウムの取込み比を求めることにより，トリチウム取込み率に対するハロゲン置換の効果を明ら かにすることができた。これらの知見に基ついて反応機構について議論する。 